This is the peer reviewed version of the following article: Angew. Chem. Int. Ed. 2014, 53, 11587-11591, which has been published in final form at:

Intermetallics

\title{
Temperature-dependant Electron Shuffle in Molecular Group 13/15 Intermetallic Complexes
}

\author{
Chelladurai Ganesamoorthy, Dieter Bläser, Christoph Wölper, Stephan Schulz*
}

Dedicated to Prof. Dr. R. Zellner on the occasion of his 70th birthday

\begin{abstract}
Mono-valent $\mathrm{RAl}\left(\mathrm{R}=\mathrm{HC}\left[\mathrm{C}(\mathrm{Me}) \mathrm{N}\left(2,6-i-\mathrm{Pr}_{2} \mathrm{C}_{6} \mathrm{H}_{3}\right)\right]_{2}\right)$ reacts with $E_{2} E t_{4}(E=S b, B i)$ with insertion into the weak $E-E$ bond and subsequent formation of $R_{A l}\left(E E t_{2}\right)_{2}(E=S b 1 ; B i 2)$. The analogous reaction of $R G a$ with $E_{2} E t_{4}$ yields a temperaturedependant equilibrium between $R G a\left(E E t_{2}\right)_{2}(E=S b 3 ; B i$ 4) and the starting reagents. RIn does not interact with $\mathrm{Sb}_{2} E t_{4}$ under various reaction conditions, but formation of $\operatorname{RIn}\left(B i E t_{2}\right)_{2}$ (5) was observed in the reaction with $\mathrm{Bi}_{2} E t_{4}$ at low temperature.
\end{abstract}

Since the discovery of the first mono-valent group 13 diyl $\mathrm{Cp}^{*} \mathrm{Al}$ more than 20 years ago, ${ }^{[1]}$ compounds of the general type $\mathrm{R}^{\prime} \mathrm{M}[\mathrm{M}=$ $\mathrm{Al}, \mathrm{Ga} ; \mathrm{R}^{\prime}=\mathrm{Cp}^{*}$, diketiminates, ...] have emerged from laboratory curiosities to versatile compounds in inorganic and organic syntheses. ${ }^{[2]}$ The powerful reducing activity of $\beta$-diketiminate aluminum and gallium complexes make them very unique and they were used for the activation of small molecules such as azides, diimines, $\mathrm{O}_{2}, \mathrm{~S}_{8}, \mathrm{P}_{4}$, acetylene and others. ${ }^{[3]}$ Reduction reactions of $\mathrm{RGa}$ with main metal compounds such as $\mathrm{SnCl}_{2}{ }^{[4]}$ and $\mathrm{Bi}\left(\mathrm{OR}^{\prime \prime}\right)_{3}{ }^{[5]}$ yielded novel gallyl-supported tin clusters $\left[\mathrm{Sn}_{7}\{\mathrm{Ga}(\mathrm{Cl})(\mathrm{R})\}_{2}\right]$ and $\left[\mathrm{Sn}_{17}\{\mathrm{Ga}(\mathrm{Cl})(\mathrm{R})\}_{4}\right]$ and galla-dibismuthenes $[\mathrm{RGa}(\mathrm{OR}) \mathrm{Bi}]_{2}\left(\mathrm{R}^{\prime \prime}=\right.$ $\mathrm{C}_{6} \mathrm{~F}_{5}, \mathrm{SO}_{2} \mathrm{CF}_{3}$ ). These reactions straightforwardly proceeded with oxidation of the group 13 metal and subsequent metal-metal bond formation. Mono-valent group 13 complexes RM were also found to serve as unique ligands in transition metal chemistry due to the presence of a metal-centered electron lone pair. ${ }^{[6]}$ Metal olefin, carbonyl and isonitrile complexes were found to react with $\mathrm{MR}^{\prime}$ with substitution of the carbonyl group and formation of intermetallic cluster complexes as was reported by Fischer et al. ${ }^{[7]}$

Despite these significant findings, there still remains interest in understanding the bonding situation in intermetallic compounds containing only weak metal-metal interactions and how the electrons interact in these complexes. Due to our general interest in weak metal-metal bonding, ${ }^{[8]}$ in particular in group 13-Bi compounds, ${ }^{[9]}$ we became interested in reactions of mono-valent group 13 compounds $\mathrm{RM}\left(\mathrm{M}=\mathrm{Al},{ }^{[10]} \mathrm{Ga}^{[11]} \mathrm{In}^{[12]} ;(\mathrm{R}=\mathrm{HC}[\mathrm{C}(\mathrm{Me}) \mathrm{N}(2,6-i-\right.$ $\left.\left.\operatorname{Pr}_{2} \mathrm{C}_{6} \mathrm{H}_{3}\right)\right]_{2}$ ) with low-valent group 15 complexes of the general type $\mathrm{Et}_{2} \mathrm{E}_{-} \mathrm{EEt}_{2}$ containing the heaviest group 15 elements, $\mathrm{Sb}$ and $\mathrm{Bi}^{\left[{ }^{[13]}\right.}$ We herein report on the formation of a temperature-dependant

[*] Dr. C. Ganesamoorthy, D. Bläser, Dr. C. Wölper, Prof. Dr. S. Schulz Faculty of Chemistry, University of Duisburg-Essen Universitätsstr. 5-7, S07 S03 C30, D-45117 Essen Fax: (+) 201-183 3830

E-mail: stephan.schulz@uni-due.de

[**] S. Schulz gratefully acknowledges financial support by the University of Duisburg-Essen.

Supporting information for this article is available on the WWW under http://www.angewandte.org or from the author. equilibrium between metal-metal bonded species $\mathrm{RM}\left(\mathrm{EEt}_{2}\right)_{2}$ and the starting reagents $\mathrm{RM}$ and $\mathrm{E}_{2} \mathrm{Et}_{4}$.

Equimolar reactions of $\mathrm{RAl}$ with $\mathrm{E}_{2} \mathrm{Et}_{4}(\mathrm{E}=\mathrm{Sb}, \mathrm{Bi})$ in toluene occurred with insertion of RAl into the E-E bond and formation of $\operatorname{RAl}\left(\mathrm{EEt}_{2}\right)_{2}(\mathrm{E}=\mathrm{Sb} \mathbf{1} ; \mathrm{Bi} \mathbf{2})$ in moderate yields. $\mathbf{1}$ and $\mathbf{2}$ are air and moisture sensitive and soluble in common organic solvents. $\mathbf{1}$ is stable in solution whereas $\mathbf{2}$ slowly decomposes with formation of $\mathrm{BiEt}_{3}$ and elemental $\mathrm{Bi} .{ }^{1} \mathrm{H}$ and ${ }^{13} \mathrm{C}$ NMR spectra of freshly prepared 1 and $\mathbf{2}$ show characteristic resonances of the organic substituents, i.e. the ${ }^{1} \mathrm{H}$ NMR spectrum of $\mathbf{1}$ in $\mathrm{C}_{6} \mathrm{D}_{6}$ exhibits single resonances for the $\gamma-\mathrm{H}$ and two methyl groups of the $\mathrm{C}_{3} \mathrm{~N}_{2} \mathrm{Al}$ ring at 4.94 and $1.52 \mathrm{ppm}$, respectively. The diastereotopic methyl protons of the isopropyl substituents appear as two doublets at 1.14 and $1.51 \mathrm{ppm}$ and the methine proton as septet at $3.61 \mathrm{ppm}$. A triplet and a multiplet at 1.40 and $1.73 \mathrm{ppm}$ confirm the presence of the ethyl groups. The ${ }^{13} \mathrm{C}\left\{{ }^{1} \mathrm{H}\right\}$ NMR spectrum of $\mathbf{1}$ shows 12 signals as was expected including the characteristic resonances due to the $\gamma-\mathrm{CH}$ (100.40 ppm), the remaining two $\mathrm{C}_{3} \mathrm{~N}_{2} \mathrm{Al}$ ring carbons (172.42 ppm) the methine $(29.61 \mathrm{ppm})$ and the methyl carbon atoms of isopropyl groups $(26.73,25.94 \mathrm{ppm})$ as well as the methyl (17.33 ppm) and methylene carbon atoms $(-3.33 \mathrm{ppm})$ of the ethyl groups. ${ }^{1} \mathrm{H}$ and ${ }^{13} \mathrm{C}$ NMR spectra of $\mathbf{1}$ and $\mathbf{2}$ indicate the $\mathrm{C}_{2 \mathrm{v}}$ symmetric structure related to the $\beta$-diketiminate ligands.
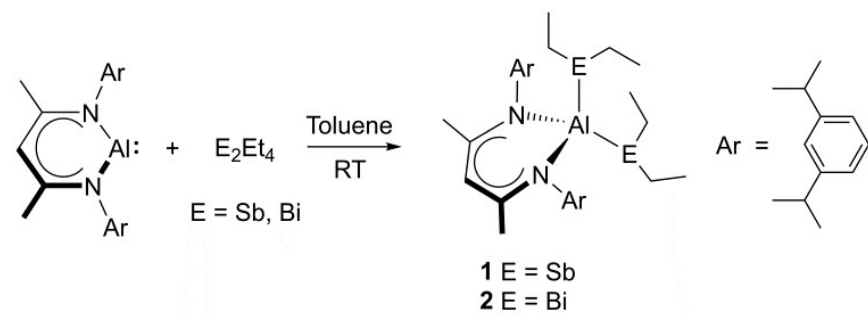

Scheme 1. Synthesis of 1 and 2.

The reactions of equimolar amounts of $\mathrm{RGa}$ with $\mathrm{E}_{2} \mathrm{Et}_{4}$ differ significantly from those of RAl. Yellow crystals of RGa(SbEt $)_{2}(3)$ were isolated from a reaction with $\mathrm{Sb}_{2} \mathrm{Et}_{4}$ in hexane at $-30{ }^{\circ} \mathrm{C}$. The ${ }^{1} \mathrm{H}$ NMR spectrum of isolated crystals shows resonances due to $\mathbf{3}$ as well as traces of RGa, which could not be excluded by repeated recrystallization. Elemental analysis $(\mathrm{C}, \mathrm{H}, \mathrm{N})$ of $\mathbf{3}$, however, confirms its analytically pure nature. The temperature sensitivity of M-E $\sigma$ bonded compounds is well known, i.e. $\left[\mathrm{Me}_{2} \mathrm{GaBi}\left(\mathrm{SiMe}_{3}\right)_{2}\right]_{3}$ decomposes in non-coordinating solvents with formation of $\mathrm{Me}_{3} \mathrm{Ga}$, $\mathrm{Bi}_{2}\left(\mathrm{SiMe}_{3}\right)_{4}$ and elemental $\mathrm{Ga}$, whereas in coordination solvents the formation of $\left(\mathrm{Me}_{3} \mathrm{Si}\right)_{3} \mathrm{Bi}, \mathrm{Me}_{3} \mathrm{Ga}$ and an insoluble metallic precipitate was observed. ${ }^{[9 \mathrm{~d}]}$ We therefore investigated the thermal stability of 3 in $\mathrm{C}_{6} \mathrm{D}_{6}$ by temperature-variable ${ }^{1} \mathrm{H}$ NMR spectroscopy. 


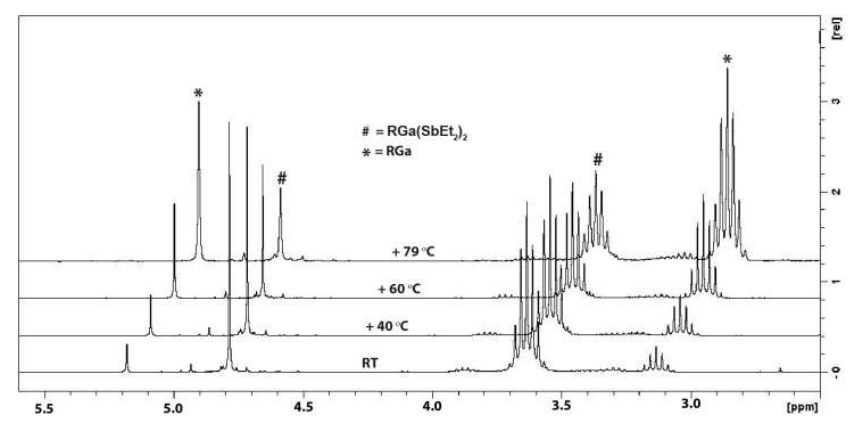

Figure 1. Temperature-dependant ${ }^{1} \mathrm{H}$ NMR study of isolated crystals of 3 ; the relative intensity of the signals of $\mathbf{3}(\#)$ and $\mathrm{RGa}\left({ }^{*}\right)$ are clearly temperaturedependant and fully reversible.

3 starts to dissociate at $40{ }^{\circ} \mathrm{C}$ into $\mathrm{RGa}$ and $\mathrm{Sb}_{2} \mathrm{Et}_{4}$ and the dissociation gradually increased at $60{ }^{\circ} \mathrm{C}$ and $80{ }^{\circ} \mathrm{C}$ (Figure 1). Cooling the reaction solution back to $25{ }^{\circ} \mathrm{C}$ resulted in an increase of the resonances due to $\mathbf{3}$ and a decrease of the resonances due to $\mathrm{RGa}$ and $\mathrm{Sb}_{2} \mathrm{Et}_{4}$, respectively, demonstrating that 3 shows a very unique chemical equilibrium with $\mathrm{RGa}$ and $\mathrm{Et}_{4} \mathrm{Sb}_{2}$ (scheme 2). The position of this equilibrium depends on the reaction temperature, indicating comparable metal-metal bond strengths of the $\mathrm{Ga}-\mathrm{Sb}$ and the $\mathrm{Sb}-\mathrm{Sb}$ bonds. The decreasing concentration of $\mathbf{3}$ with increasing temperature is therefore most likely entropy driven.

Comparable results were observed for the reaction of $\mathrm{RGa}$ with $\mathrm{Bi}_{2} \mathrm{Et}_{4}$. Isolation of analytically pure $\mathrm{RGa}\left(\mathrm{BiEt}_{2}\right)_{2}$ (4) from the $1: 1$ mixture of $\mathrm{RGa}$ and $\mathrm{Bi}_{2} \mathrm{Et}_{4}$ (Figure S9) was even more difficult since under diluted conditions spontaneous crystallization of RGa occurred. However, pure 4 was isolated in good amount by changing the molar ratio of $\mathrm{RGa}$ and $\mathrm{Bi}_{2} \mathrm{Et}_{4}$ into 1:2. Under these conditions, the molar ratio of 4 to RGa increases up to 5:1 (Figure S10). The ${ }^{1} \mathrm{H}$ NMR spectrum of isolated crystals of $\mathbf{4}$ again shows a 1:1 molar ratio of $\mathbf{4}$ and $\mathrm{RGa}$, clearly proving the formation of an equilibrium. Analytical data of $\mathbf{3}$ and $\mathbf{4}$ show their pure nature in solid state. $\mathbf{3}$ and $\mathbf{4}$ are stable at ambient temperature, but their stability in solution is significantly reduced due to the formation of $\mathrm{E}_{2} \mathrm{Et}_{4}$, which are only fairly stable in solution. ${ }^{1} \mathrm{H}$ and ${ }^{13} \mathrm{C}$ NMR spectra of $\mathbf{3}$ and $\mathbf{4}$ are similar to those of $\mathbf{1}$ and $\mathbf{2}$. Even though the extent of shifts of the resonances in the ${ }^{1} \mathrm{H}$ NMR compared to the free ligands RM differs, they all show a similar pattern, i.e. the $\gamma-\mathrm{H}$ and the methyl protons of $\beta$-diketiminate ligand are shifted to higher field whereas the isopropyl groups of the phenyl rings are shifted to lower field.

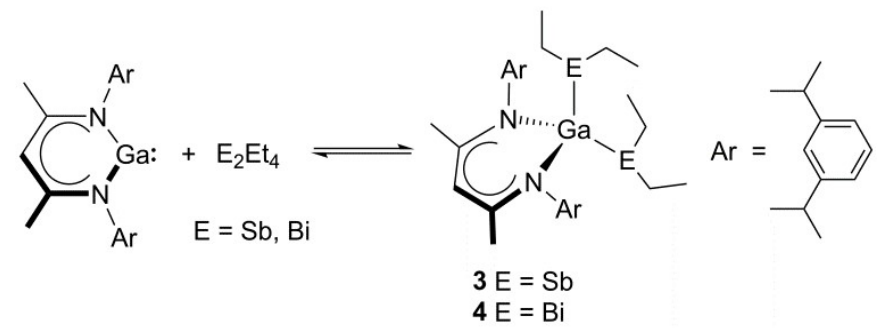

Scheme 2. Chemical equilibrium of 3 and 4 with $R G a$ and $E_{2} E_{4}$.
As the basicity considerably decreases from $\mathrm{Al}^{\mathrm{I}}$ to $\mathrm{Ga}^{\mathrm{I}}$ and $\mathrm{In}^{\mathrm{I}}$, it is reasonable to assume even weaker bonding interactions between RIn and $\mathrm{E}_{2} \mathrm{Et}_{4}$. In fact, RIn did not react with $\mathrm{Sb}_{2} \mathrm{Et}_{4}$, whereas its reaction with $\mathrm{Bi}_{2} \mathrm{Et}_{4}$ at ambient temperature gave traces $(9 \%)$ of a new set of resonances which point to the formation of $\operatorname{RIn}\left(\mathrm{BiEt}_{2}\right)_{2}$ (5). Based on the integration of the starting compound RIn and the product 5 in the ${ }^{1} \mathrm{H}$ NMR spectra, the concentration of $\mathbf{5}$ increases with increasing the concentration of $\mathrm{Bi}_{2} \mathrm{Et}_{4}$ from one to four molar ratio $(26 \%)$ as well as by cooling the $1: 1$ reaction mixture to $-60{ }^{\circ} \mathrm{C}$ (19\%), also indicating the presence of a chemical equilibrium as was observed for $\mathbf{3}$ and $\mathbf{4}$. Unfortunately, isolation of $\mathbf{5}$ from the mixtures was not possible since at low temperatures, RIn crystallizes much faster than $\mathbf{5}$, whereas decomposition of $\mathrm{Bi}_{2} \mathrm{Et}_{4}$ occurred at ambient temperature. It should be noted that no such reversible equilibrium phenomenon was observed for 1 at $80{ }^{\circ} \mathrm{C}$ (Figure S3). A temperature-dependent NMR experiment was not carried out for 2 due to its temperature sensitivity.

Reversible activation reactions of p-block element compounds are rare and almost limited to the activation of small molecules such as $\mathrm{H}_{2}$ and $\mathrm{CO}_{2}$ by frustrated Lewis pairs (FLP). ${ }^{[14]}$ Nikonov et al. reported on the reversible reaction of $\mathrm{RAl}$ and $\mathrm{RAlH}_{2}$, yielding the dialane $\mathrm{R}(\mathrm{H}) \mathrm{Al}-\mathrm{Al}(\mathrm{H}) \mathrm{R} .{ }^{[15]}$ In addition, alkynes reversibly react with Lappert's stannylene $\left[\left(\mathrm{Me}_{3} \mathrm{Si}\right)_{2} \mathrm{CH}\right]_{2} \mathrm{Sn}$ and with a digallane, ${ }^{[16,17]}$ whereas the reversible, temperature controlled binding and release of $\mathrm{C}_{2} \mathrm{H}_{4}$ was observed in reactions with a distannyne and with $\mathrm{Si}(\mathrm{II})$ complexes. ${ }^{[18,19]}$ Power et al. reported on the reversible, photoinduced activation of $\mathrm{P}_{4}$ by reaction with a $\mathrm{Ge}(\mathrm{II})$ compound. ${ }^{[20]}$ In contrast, the formation of a fully reversible equilibrium between a low-valent main group metal complex and the corresponding intermetallic complex is without precedence.

Single crystals of $\mathbf{1}-\mathbf{4}$ suitable for X-ray diffraction analysis were grown from saturated $n$-hexane solutions. $\mathbf{1}-\mathbf{4}$ crystallize in the monoclinic space groups $P 2_{1} / c(\mathbf{1}-\mathbf{3})$ and $P 2{ }_{1} / n(\mathbf{4}){ }^{[21]}$ Since the conformation in $\mathbf{1 - 4}$ is roughly the same, only the solid state structure of $\mathbf{4}$ is presented in Figure 2. Crystal data and the details of the structure determinations are summarized in the SI file.

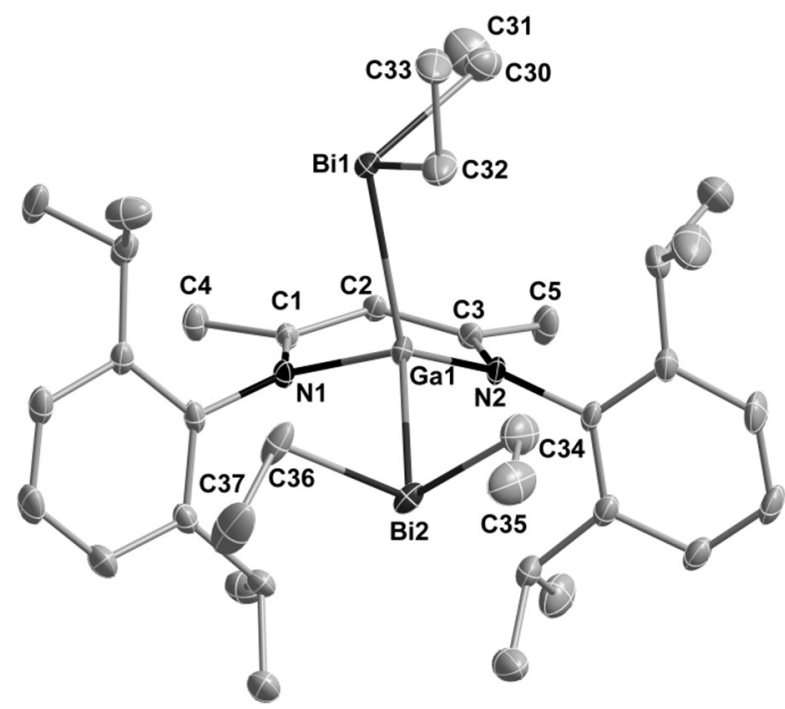

Figure 2. Molecular structure of $\mathrm{RGa}\left(\mathrm{BiEt}_{2}\right)_{2}$ 4. $\mathrm{H}$-atoms and second orientation of the disordered $\mathrm{BiEt}_{2}$-group have been omitted for clarity and displacement ellipsoids are drawn at the $30 \%$ probability level. M-E bond lengths are 2.6586(7), 2.7169 (7) $\AA$ (1); 2.7318(16), 2.804(2) $\AA$ (2); 2.6246(3), 2.6743(5) $\AA$ (3); 2.6961(6), 2.7303(10) ^̊ (4) 
The group 13 metal atoms in $\mathbf{1}-\mathbf{4}$ each adopt a distorted tetrahedral geometry, whereas the group 15 metal atoms show pyramidal coordination spheres. In contrast to the planar $\mathrm{C}_{3} \mathrm{~N}_{2} \mathrm{M}$ rings in the starting reagents $R M$, the metal atom $M$ in the $\mathrm{C}_{3} \mathrm{~N}_{2} \mathrm{M}$ heterocycles in $\mathbf{1}-\mathbf{4}$ is out of plane (deviation from best plane of the ligand backbone 0.781(2) $\AA 1,0.801(6) \AA 2,0.850(3) \AA 3,0.862(5)$ $\AA$ 4). The bite angles of the chelating organic ligand $\mathrm{R}$ are $97.39(8)^{\circ}$ $(1), 97.16(18)^{\circ}(2), 94.86(8)^{\circ}(3)$ and $94.27(15)^{\circ}(4)$, respectively. The two independent Al-N distances in $\mathbf{1}$ and $\mathbf{2}$ differ only slightly

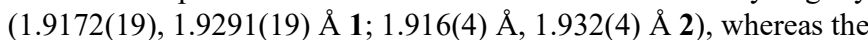
Al-E bond lengths vary significantly $(2.6586(7), 2.7169$ (7) $\AA$ 1; 2.7318(16), 2.804(2) $\AA$ 2), probably due to the disorder of one EEt 2 group. The Ga-N bond lengths in 3 (1.990(2), 2.0059(19) $\AA$ ) and 4 (1.991(4), 2.013(4) $\AA$ ) are elongated compared to the Al-N bond lengths in 1 and 2, whereas the Ga-E bond lengths (2.6246(3),

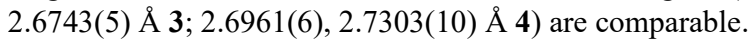

The M-N bond distances in $\mathbf{1} \mathbf{- 4}$ are significantly shorter than those observed in the starting reagents $R M,{ }^{[10,11]}$ which results from the change of the formal oxidation states of the group 13 metal atoms from $+\mathrm{I}$ to $+\mathrm{III}$. The M-E bonds are also shorter compared to those observed in the acid-base adducts such as $t-\mathrm{Bu}_{3} \mathrm{AlSbR}_{3}(\mathrm{R}=$ Et 2.845(1) $\AA, i$-Pr 2.9267(4) $\AA), \mathrm{R}_{3} \mathrm{AlSb} t-\mathrm{Bu} 3(\mathrm{R}=\mathrm{Me} 2.834(1) \AA$; Et $2.873(1) \AA),{ }^{[22]} \mathrm{Et}_{3} \mathrm{AlSb}\left(\mathrm{SiMe}_{3}\right)_{3}(2.841(1) \AA),{ }^{[23]} t$-Bu3 $\mathrm{BaSbR}_{3}$ $(\mathrm{R}=\mathrm{Et}, 2.8479(5) \AA ; i-\mathrm{Pr}, 2.9618(2) \AA),{ }^{[24]} t-\mathrm{Bu}_{3} \mathrm{MBi}-\mathrm{Pr}_{3}(\mathrm{M}=\mathrm{Al}$, $\left.\left.3.088(1) \AA{ }^{[25]} \mathrm{Ga}, 3.135(1) \AA\right),{ }^{[9 b]}\right)\left(\mathrm{Et}_{4} \mathrm{Bi}_{2}\right)\left(\mathrm{Mt}-\mathrm{Bu}_{3}\right)_{2}(\mathrm{M}=\mathrm{Al}$, 3.084(1); Ga, 3.099(2), 3.114(2) $\AA),{ }^{[9 c]} \mathrm{Et}_{3} \mathrm{MBi}\left(\mathrm{SiMe}_{3}\right)_{3}(\mathrm{M}=\mathrm{Al}$ 2.921(2) $\left.\AA,{ }^{[25]} \mathrm{Ga} 2.966(1) \AA^{[9 b]}\right)$, but comparable to the sum of the respective covalent radii. ${ }^{[26]}$ Moreover, they agree with those observed in M-E $\sigma$-bonded compounds $\left[\mathrm{R}_{2} \mathrm{MER}_{2}\right]_{2}$ and (dmap)M( $\left.\mathrm{R}_{2}\right) \mathrm{ER}_{2}(\mathrm{M}=\mathrm{Al}, \mathrm{Ga} ; \mathrm{E}=\mathrm{Sb}, \mathrm{Bi} ; \mathrm{R}=$ alkyl, R' = alkyl, $\mathrm{SiMe}_{3} ;$ dmap $=4$-dimethylamino pyridine). ${ }^{[27,28]}$ The distances between the two group 15 elements in $\mathbf{1}-\mathbf{4}$ are too far to be considered for any possible bonding interactions. The E-M-E angles of the major component of the disorder are $117.33(3)^{\circ}$ (1), $118.42(12)^{\circ}(2), 119.155(17)(3)$ and 119.89(7) (4), however due to the disorder they are only of limited reliability.

In summary, monovalent RAl reacts straightforward with $\mathrm{Et}_{4} \mathrm{E}_{2}$ $(\mathrm{E}=\mathrm{Sb}, \mathrm{Bi})$ with insertion into the metal-metal bond and formation of $\mathrm{RAl}\left(\mathrm{EEt}_{2}\right)_{2}$, whereas the insertion reaction of $\mathrm{RGa}$ into $\mathrm{Et}_{4} \mathrm{E}_{2}$ is fully reversible and temperature dependant. In contrast, RIn only reacted with $\mathrm{Bi}_{2} \mathrm{Et}_{4}$ at ambient temperature with formation of $\mathrm{RIn}\left(\mathrm{BiEt}_{2}\right)_{2}(\mathbf{5})$ in very low yield. 1 - 5 represent rare examples of metal organic complexes of heavy group 15 elements $(\mathrm{Sb}, \mathrm{Bi})$, in which the group 13/15 molar ratio is $1: 2 .{ }^{[29]}$

\section{Experimental Section}

\section{Experimental Section}

General Procedures. All manipulations were performed in $\mathrm{Ar}$ atmosphere using standard Schlenk and glove-box techniques. Toluene and hexane were dried using mBraun Solvent Purification System. Deuterated solvents were dried over activated molecular sieves $(4 \AA)$ and degassed prior to use. Starting reagents $\mathrm{RM}\left(\mathrm{R}=\mathrm{HC}\left[\mathrm{C}(\mathrm{Me}) \mathrm{N}\left(2,6-{ }^{i} \mathrm{Pr}_{2} \mathrm{C}_{6} \mathrm{H}_{3}\right)\right]_{2} ; \mathrm{M}=\mathrm{Al}, \mathrm{Ga} \text { and } \mathrm{In}\right)^{[10-12]}$ and $\mathrm{E}_{2} \mathrm{Et}_{4}$ $(\mathrm{E}=\mathrm{Sb}, \mathrm{Bi})^{[30]}$ were prepared by literature methods. ${ }^{1} \mathrm{H}(300 \mathrm{MHz})$ and ${ }^{13} \mathrm{C}\left\{{ }^{1} \mathrm{H}\right\}$ (75.5 MHz) NMR spectra were recorded using a Bruker Avance DPX-300 spectrometer and referenced to internal $\mathrm{C}_{6} \mathrm{D}_{5} \mathrm{H}\left({ }^{1} \mathrm{H}: \delta=7.15 ;{ }^{13} \mathrm{C}: \delta=128.62\right)^{[31]}$ and IR spectra in a glovebox using an ALPHA-T FT-IR spectrometer equipped with a single reflection ATR sampling module. Microanalyses were performed the elemental analysis laboratory of University of Duisburg-Essen.

Synthesis of RAl(SbEt $)_{2}$ (1). A solution of RAl $(60 \mathrm{mg}, 0.135 \mathrm{mmol}$ ) and $\mathrm{Sb}_{2} \mathrm{Et}_{4}(48.6 \mathrm{mg}, 0.135 \mathrm{mmol}$ ) in $2 \mathrm{~mL}$ of toluene was stirred at ambient temperature for $1 \mathrm{~h}$. The solvents were removed at reduced pressure, yielding a yellow-orange residue, which was dissolved in $2 \mathrm{~mL}$ of $n$-hexane and stored at -
$30{ }^{\circ} \mathrm{C}$ for 1 day to afford analytically pure orange crystals of 1 . Yield: $60 \mathrm{mg}$ (0.112 mmol, 55 \%). Anal. Calcd. for $\mathrm{C}_{37} \mathrm{H}_{61} \mathrm{AlSb}_{2} \mathrm{~N}_{2}$ : C, 55.25; $\mathrm{H}, 7.64 ; \mathrm{N}, 3.48$. Found: C, 55.5; H, 7.75; N, 3.54\%. IR (neat): v $2959(\mathrm{~m}), 2916(\mathrm{~m}), 2853(\mathrm{~m})$, $1512(\mathrm{~m}), 1433(\mathrm{w}), 1369(\mathrm{~s}), 1310(\mathrm{~m}), 1251(\mathrm{~m}), 1167(\mathrm{~m}), 1097(\mathrm{~m}), 1013(\mathrm{~s})$, $933(\mathrm{~m}), 864(\mathrm{~m}), 794(\mathrm{~s}), 752(\mathrm{~m}), 683(\mathrm{w}), 635(\mathrm{w}), 528(\mathrm{w}), 486(\mathrm{w}), 443(\mathrm{w})$, $401(\mathrm{~m}) \mathrm{cm}^{-1} .{ }^{1} \mathrm{H}$ NMR $\left(\mathrm{C}_{6} \mathrm{D}_{6}, 300 \mathrm{MHz}\right): \delta 7.14\left(\mathrm{~s}, 6 \mathrm{H}, \mathrm{C}_{6} \mathrm{H}_{3}\left({ }^{(} \mathrm{Pr}\right)_{2}\right), 4.94(\mathrm{~s}, 1 \mathrm{H}$, $\gamma-\mathrm{CH}$ ), 3.61 (sept, $\left.4 \mathrm{H},-\mathrm{CH}\left(\mathrm{CH}_{3}\right)_{2}\right), 1.73\left(\mathrm{~m}, 8 \mathrm{H},-\mathrm{CH}_{2} \mathrm{CH}_{3}\right), 1.52(\mathrm{~s}, 6 \mathrm{H}$ ArNCCH $\left.H_{3}\right), 1.50\left(\mathrm{~d}, 12 \mathrm{H},-\mathrm{CH}\left(\mathrm{CH}_{3}\right)_{2}\right), 1.40\left(\mathrm{t}, 12 \mathrm{H},-\mathrm{CH}_{2} \mathrm{CH}_{3}\right), 1.14(\mathrm{~d}, 12 \mathrm{H}, \mathrm{J}$ $\left.=6.6 \mathrm{~Hz},-\mathrm{CH}\left(\mathrm{CH}_{3}\right)_{2}\right) \cdot{ }^{13} \mathrm{C} \mathrm{NMR}\left(\mathrm{C}_{6} \mathrm{D}_{6}, 75.5 \mathrm{MHz}\right): \delta 172.42\left(\mathrm{ArNCCH}_{3}\right), 145.12$ $\left(\mathrm{C}_{6} \mathrm{H}_{3}\right), 141.69\left(\mathrm{C}_{6} \mathrm{H}_{3}\right), 127.98\left(\mathrm{C}_{6} \mathrm{H}_{3}\right), 125.52\left(\mathrm{C}_{6} \mathrm{H}_{3}\right), 100.40(\gamma-\mathrm{CH}-), 29.61(-$ $\left.\mathrm{CH}\left(\mathrm{CH}_{3}\right)_{2}\right), 26.73\left(-\mathrm{CH}\left(\mathrm{CH}_{3}\right)_{2}\right), 25.94\left(-\mathrm{CH}\left(\mathrm{CH}_{3}\right)_{2}\right), 24.44\left(\mathrm{ArNCCH}_{3}\right), 17.33$ $\left(\mathrm{BiCH}_{2} \mathrm{CH}_{3}\right), 1.76\left(\mathrm{BiCH}_{2} \mathrm{CH}_{3}\right),-3.33\left(\mathrm{BiCH}_{2} \mathrm{CH}_{3}\right)$

Synthesis of $\mathrm{RAI}\left(\mathrm{BiEt}_{2}\right)_{2}$ (2). 2 was synthesized by a procedure similar to that of 1 using RAl (87.5 mg, $0.197 \mathrm{mmol}$ ) and $\mathrm{Bi}_{2} \mathrm{Et}_{4}(105.1 \mathrm{mg}, 0.197 \mathrm{mmol})$. Yield: $110 \mathrm{mg}$ (0.112 mmol, 57 \%). Anal. Calcd. for $\mathrm{C}_{37} \mathrm{H}_{61} \mathrm{AlBi}_{2} \mathrm{~N}_{2}$ : C, 45.40; $\mathrm{H}, 6.28$; $\mathrm{N}, 2.86$. Found: C, 45.90; H, 6.32; N, 2.76\%. IR (neat): v $2970(\mathrm{~m}), 2926(\mathrm{~m})$, $2849(\mathrm{~m}), 1519(\mathrm{~m}), 1431(\mathrm{w}), 1365(\mathrm{~s}), 1310(\mathrm{~m}), 1255(\mathrm{w}), 1173(\mathrm{w}), 1129(\mathrm{~m})$ $1013(\mathrm{~m}), 936(\mathrm{~m}), 859(\mathrm{~m}), 793(\mathrm{~m}), 755(\mathrm{~m}), 634(\mathrm{w}), 524(\mathrm{w}), 436(\mathrm{~m}), 397$ (m) $\mathrm{cm}^{-1} .{ }^{1} \mathrm{H}$ NMR $\left(\mathrm{C}_{6} \mathrm{D}_{6}, 300 \mathrm{MHz}\right): \delta 7.13\left(\mathrm{~s}, 6 \mathrm{H}, \mathrm{C}_{6} \mathrm{H}_{3}\left({ }^{(} \mathrm{Pr}\right)_{2}\right), 4.95(\mathrm{~s}, 1 \mathrm{H}, \gamma$ $\mathrm{CH}$ ), 3.52 (sept, $\left.4 \mathrm{H},-\mathrm{CH}\left(\mathrm{CH}_{3}\right)_{2}\right), 2.37\left(\mathrm{~m}, 8 \mathrm{H},-\mathrm{CH}_{2} \mathrm{CH}_{3}\right), 1.99$ (t, $12 \mathrm{H}$, $\left.\mathrm{CH}_{2} \mathrm{CH}_{3}\right), 1.54\left(\mathrm{~s}, 6 \mathrm{H}, \mathrm{ArNCCH}_{3}\right), 1.48\left(\mathrm{~d}, 12 \mathrm{H}, \mathrm{J}=6.9 \mathrm{~Hz},-\mathrm{CH}\left(\mathrm{CH}_{3}\right)_{2}\right), 1.16$ (d $\left.12 \mathrm{H},-\mathrm{CH}\left(\mathrm{CH}_{3}\right)_{2}\right) .{ }^{13} \mathrm{C}$ NMR $\left(\mathrm{C}_{6} \mathrm{D}_{6}, 75.5 \mathrm{MHz}\right): \delta 172.82\left(\mathrm{ArNCCH}_{3}\right), 145.15$ $\left(\mathrm{C}_{6} \mathrm{H}_{3}\right), 141.89\left(\mathrm{C}_{6} \mathrm{H}_{3}\right), 127.96\left(\mathrm{C}_{6} \mathrm{H}_{3}\right), 125.49\left(\mathrm{C}_{6} \mathrm{H}_{3}\right), 100.84(\gamma-\mathrm{CH}-), 30.33(-$ $\left.\mathrm{CH}\left(\mathrm{CH}_{3}\right)_{2}\right), 26.97\left(-\mathrm{CH}\left(\mathrm{CH}_{3}\right)_{2}\right), 26.05\left(-\mathrm{CH}\left(\mathrm{CH}_{3}\right)_{2}\right), 24.50\left(\mathrm{ArNCCH}_{3}\right), \quad 18.35$ $\left(\mathrm{BiCH}_{2} \mathrm{CH}_{3}\right),-9.17\left(\mathrm{BiCH}_{2} \mathrm{CH}_{3}\right)$.

Synthesis of $\mathrm{RGa}\left(\mathrm{SbEt}_{2}\right)_{2}$ (3). This was synthesized by a procedure similar to that of 1 using RGa (90 mg, $0.185 \mathrm{mmol})$ and $\mathrm{Sb}_{2} \mathrm{Et}_{4}(66.4 \mathrm{mg}, 0.185 \mathrm{mmol})$. Yield: $87 \mathrm{mg}(0.114 \mathrm{mmol}, 62 \%)$. Anal. Calcd. for $\mathrm{C}_{37} \mathrm{H}_{61} \mathrm{GaSb}_{2} \mathrm{~N}_{2}$ : C, 52.46; $\mathrm{H}$, 7.26; N, 3.31. Found: C, 52.7; H, 7.28; N, 3.35\%. IR (neat): v 2964 (m), 2922 $(\mathrm{m}), 2858(\mathrm{~m}), 1550(\mathrm{~m}), 1512(\mathrm{~m}), 1433(\mathrm{~m}), 1374(\mathrm{~s}), 1310(\mathrm{~m}), 1257(\mathrm{w})$, $1167(\mathrm{~m}), 1108(\mathrm{w}), 1013(\mathrm{~m}), 938(\mathrm{~m}), 853(\mathrm{w}), 794(\mathrm{~m}), 752(\mathrm{~m}), 683(\mathrm{w}), 619$ (w), $523(w), 486(w), 433(w) \mathrm{cm}^{-1} .{ }^{1} \mathrm{H}$ NMR $\left(\mathrm{C}_{6} \mathrm{D}_{6}, 300 \mathrm{MHz}\right): \delta 7.14(\mathrm{~m}, 6 \mathrm{H}$, $\left.\mathrm{C}_{6} \mathrm{H}_{3}(\mathrm{Pr})_{2}\right), 4.78(\mathrm{~s}, 1 \mathrm{H}, \gamma-\mathrm{CH}$ ) $), 3.64$ (sept, $\left.4 \mathrm{H},-\mathrm{CH}\left(\mathrm{CH}_{3}\right)_{2}\right), 1.72(\mathrm{~m}, 8 \mathrm{H}$, $\left.\mathrm{CH}_{2} \mathrm{CH}_{3}\right), 1.56(\mathrm{~s}, 6 \mathrm{H}, \operatorname{ArNCCH})_{3}, 1.50\left(\mathrm{~d}, 12 \mathrm{H},-\mathrm{CH}\left(\mathrm{CH}_{3}\right)_{2}\right), 1.32$ (t, $12 \mathrm{H},-$ $\left.\mathrm{CH}_{2} \mathrm{CH}_{3}\right), 1.18\left(\mathrm{~d}, 12 \mathrm{H}, \mathrm{J}=6.6 \mathrm{~Hz},-\mathrm{CH}\left(\mathrm{CH}_{3}\right)_{2}\right) .{ }^{13} \mathrm{C} \mathrm{NMR}\left(\mathrm{C}_{6} \mathrm{D}_{6}, 75.5 \mathrm{MHz}\right): \delta$ $169.92\left(\mathrm{ArNCCH}_{3}\right), 144.97\left(\mathrm{C}_{6} \mathrm{H}_{3}\right), 143.29\left(\mathrm{C}_{6} \mathrm{H}_{3}\right), 127.48\left(\mathrm{C}_{6} \mathrm{H}_{3}\right), 125.32\left(\mathrm{C}_{6} \mathrm{H}_{3}\right)$, $98.80(\gamma-\mathrm{CH}-), 29.34\left(-\mathrm{CH}\left(\mathrm{CH}_{3}\right)_{2}\right), 26.65\left(-\mathrm{CH}\left(\mathrm{CH}_{3}\right)_{2}\right), 25.99\left(-\mathrm{CH}\left(\mathrm{CH}_{3}\right)_{2}\right), 24.39$ $\left(\mathrm{ArNCCH}_{3}\right), 16.57\left(\mathrm{SbCH}_{2} \mathrm{CH}_{3}\right),-1.27\left(\mathrm{SbCH}_{2} \mathrm{CH}_{3}\right)$.

Synthesis of $\mathrm{RGa}\left(\mathrm{BiEt}_{2}\right)_{2}$ (4). Method 1: A solution of $\mathrm{RGa}$ (228 mg, $0.468 \mathrm{mmol})$ in toluene $\left(10 \mathrm{~mL}\right.$ ) was added dropwise to a solution of $\mathrm{Bi}_{2} \mathrm{Et}_{4}$ $(250 \mathrm{mg}, 0.468 \mathrm{mmol})$ in toluene $(10 \mathrm{~mL})$ and stirred for $1 \mathrm{~h}$ at ambient temperature. The solvent was removed under reduced pressure and the resulting residue dissolved in $3 \mathrm{~mL}$ of $n$-hexane. Yellow crystals of RGa and red crystals of $\mathbf{4}$ were formed upon storage at ambient temperature after 2-3 days. Dissolution of the red crystals (4) in hexane and storage at ambient temperature again yielded a 1:1:1 mixture of $\mathrm{RGa} \mathrm{Bi}_{2} \mathrm{Et}_{4}$ and 4 (figure S9). Yield: $203 \mathrm{mg}$ $(0.199 \mathrm{mmol}, 42 \%)$. Method 2: A mixture of RGa (114 mg, $0.234 \mathrm{mmol})$ and $\mathrm{Bi}_{2} \mathrm{Et}_{4}(250 \mathrm{mg}, 0.468 \mathrm{mmol}$ ) was stirred at ambient temperature in $2 \mathrm{~mL}$ of $n$ hexane for $30 \mathrm{~min}$. The reaction mixture was kept at $-30{ }^{\circ} \mathrm{C}$ for $24 \mathrm{~h}$, yielding red crystals of analytically pure 4. Yield: $153 \mathrm{mg}(0.150 \mathrm{mmol}, 64 \%)$. Anal. Calcd. for $\mathrm{C}_{37} \mathrm{H}_{61} \mathrm{GaBi}_{2} \mathrm{~N}_{2}$ : C, 43.50; $\mathrm{H}, 6.02 ; \mathrm{N}, 2.74$. Found: C, 43.50; $\mathrm{H}, 6.03 ; \mathrm{N}$, 2.73\%. IR (neat): v $2964(\mathrm{~m}), 2916(\mathrm{~m}), 2853(\mathrm{~m}), 1545(\mathrm{w}), 1512(\mathrm{~m}), 1427(\mathrm{w})$ $1375(\mathrm{~m}), 1311(\mathrm{w}), 1258(\mathrm{~m}), 1173(\mathrm{w}), 1131(\mathrm{w}), 1098(\mathrm{~m}), 1014(\mathrm{~m}), 934(\mathrm{w})$, $849(w), 790(s), 753(w), 663(w), 519(w), 439(m), 397(w) \mathrm{cm}^{-1}$. The ${ }^{1} \mathrm{H}$ and ${ }^{13} \mathrm{C}$ NMR spectra showed the mixture of 4 and RGa. Only the resonances of 4 in the ${ }^{1} \mathrm{H}$ NMR spectrum could be assigned. ${ }^{1} \mathrm{H}$ NMR $\left(\mathrm{C}_{6} \mathrm{D}_{6}, 300 \mathrm{MHz}\right): \delta 7.14$ (m, $\left.6 \mathrm{H}, \mathrm{C}_{6} \mathrm{H}_{3}\left({ }^{\mathrm{P}} \mathrm{Pr}\right)_{2}\right), 4.79$ (s, $1 \mathrm{H}, \gamma-\mathrm{CH}$-), 3.57 (sept, $\left.4 \mathrm{H},-\mathrm{CH}\left(\mathrm{CH}_{3}\right)_{2}\right), 2.39(\mathrm{~m}, 8$ $\left.\mathrm{H},-\mathrm{CH}_{2} \mathrm{CH}_{3}\right), 1.94\left(\mathrm{t}, 12 \mathrm{H},-\mathrm{CH}_{2} \mathrm{CH}_{3}\right), 1.58\left(\mathrm{~s}, 6 \mathrm{H}, \mathrm{ArNCCH}_{3}\right), 1.48(\mathrm{~d}, 12 \mathrm{H},-$ $\left.\mathrm{CH}\left(\mathrm{CH}_{3}\right)_{2}\right), 1.20\left(\mathrm{~d}, 12 \mathrm{H}, \mathrm{J}=6.9 \mathrm{~Hz},-\mathrm{CH}\left(\mathrm{CH}_{3}\right)_{2}\right)$.

Received: ((will be filled in by the editorial staff))

Published online on ((will be filled in by the editorial staff))

Keywords: Main group elements - Metal-metal interactions • Heterometallic complexes • Donor-acceptor systems • Group 13 elements

[1] a) C. Dohmeier, C. Robl, M. Tacke, H. Schnöckel, Angew. Chem. 1991, 103, 594; Angew. Chem. Int. Ed. 1991, 30, 564; b) S. Schulz, 
H. W. Roesky, H. J. Koch, G. M. Sheldrick, D. Stalke A. Kuhn, Angew. Chem. 1993, 105, 1828; Angew. Chem. Int. Ed. 1993, 32, 1729.

[2] a) C. Dohmeier, D. Loos, H. Schnöckel, Angew. Chem. 1996, 108, 141; Angew. Chem. Int. Ed. 1996, 35, 129; b) M. N. S. Rao, H. W. Roesky, G. Anantharaman, J. Organomet. Chem. 2002, 646, 4; c) H. W. Roesky, S. S. Kumar, Chem. Commun. 2005, 4027; d) P. W. Roesky, Dalton Trans. 2009, 1887; e) M. Asay, C. Jones, M. Driess, Chem. Rev. 2011, 111, 354; f) Y.-C. Tsai, Coord. Chem. Rev. 2012, 256,722

[3] a) N. J. Hardman, C. Cui, H. W. Roesky, W.H. Fink, P. P. Power, Angew. Chem. 2001, 113, 2230; Angew. Chem. Int. Ed. 2001, 40, 2172; b) C. Cui, H. W. Roesky, H.-G. Schmidt, M. Noltemeyer, Angew. Chem. Int. Ed. 2000, 39, 4531; c) Y. Peng, H. Fan, H. Zhu, H.W. Roesky, J. Magull, C.E. Hughes, Angew. Chem. 2004, 116, 3525; Angew. Chem. Int. Ed. 2004, 43, 3443; d) G. Prabusankar, A. Doddi, C. Gemel, M. Winter, R.A. Fischer, Inorg. Chem. 2010, 49, 7976; e) H. Zhu, J. Chai, V. Jancik, H. W. Roesky, W. A. Merrill, P. P. Power, J. Am. Chem. Soc. 2005, 127, 10170; f) Y. Peng, H. Fan, V. Jancik, H. W. Roesky, R. Herbst-Irmer, Angew. Chem. 2004, 116, 6316; Angew. Chem. Int. Ed. 2004, 43, 6190; g) N. J. Hardman, P. P. Power, Inorg. Chem. 2001, 40, 2474; h) H. Zhu, Y. Chai, H. Fan, H. W. Roesky, U. N. Nehete, H.-G. Schmidt, M. Noltemeyer, Eur. J. Inorg. Chem. 2005, 2147; i) H. Zhu, J. Chai, H. Fan, H. W. Roesky, C. He, V. Jancik, H.-G. Schmidt, M. Noltemeyer, W. A. Merill, P. P. Power, Angew. Chem. 2005, 117, 5220; Angew. Chem. Int. Ed. 2005, 44,5090 .

[4] G. Prabusankar, A. Kempter, C. Gemel, M.-K. Schröter, R. A. Fischer, Angew. Chem. Int. Ed. 2008, 47, 7234

[5] G. Prabusankar, C. Gemel, P. Parameswaran, C. Flener, G. Frenking, R. A. Fischer, Angew. Chem. 2009, 121, 5634; Angew. Chem. Int. Ed. 2009, 48, 5526 .

[6] a) S. Schulz, Top. Organomet. Chem. 2013, 41, 59; b) K. H. Whitmire, Comprehensive Organometallic Chemistry, Vol. 3, C. E. Housecraft (Ed.), Elsevier 2007.

[7] a) G. Linti, H. Schnöckel, Coord. Chem. Rev. 2000, 206-207, 285; b) C. Gemel, T. Steinke, M. Cokoja, A. Kempter, R. A. Fischer, Eur. J. Inorg. Chem. 2004, 4161; c) R. J. Baker, C. Jones, Coord. Chem. Rev. 2005, 249, 1857; d) S. González-Gallardo, T. Bollermann, R. A. Fischer, R. Murugavel, Chem. Rev. 2012, 112, 3136; e) M. Molon, K. Dilchert, C. Gemel, R. W. Seidel, J. Schaumann, R. A. Fischer, Inorg. Chem. 2013, 52, 14275 .

[8] a) S. Schulz, S. Heimann, A. Kuczkowski, D. Bläser, C. Wölper, Organometallics 2013, 32, 3391; b) S. Heimann, S. Schulz, D. Bläser, C. Wölper, Eur. J. Inorg. Chem. 2013, 4909; c) S. Heimann, D. Bläser, C. Wölper, S. Schulz, Organometallics 2014, DOI: $10.1021 /$ om500208c.

[9] a) S. Schulz, M. Nieger, Angew. Chem. 1999, 111, 1020; Angew. Chem. Int. Ed. 1999, 38, 967; b) A. Kuczkowski, F. Thomas, S. Schulz, M. Nieger, Organometallics 2000, 19, 5758; c) A. Kuczkowski, S. Schulz, M. Nieger, Angew. Chem. 2001, 113, 4351; Angew. Chem. Int. Ed. 2001, 40, 4222; d) F. Thomas, S. Schulz, M. Nieger, Organometallics 2002, 21, 2793; e) F. Thomas, S. Schulz, H. Mansikkamäki, M. Nieger, Angew. Chem. 2003, 115, 5800; Angew. Chem. Int. Ed. 2003, 42, 5641; f) M. Matar, A. Kuczkowski, U. Keßler, S. Schulz, U. Flörke, Eur. J. Inorg. Chem. 2007, 2472.

[10] C. Cui, H. W. Roesky, H.-G. Schmidt, M. Noltemeyer, H. Hao, F. Cimpoesu, Angew. Chem. 2000, 112, 4444; Angew. Chem. Int. Ed. 2000, 39, 4274
[11] N. J. Hardman, B. E. Eichler, P. P. Power Chem. Commun. 2000 1991.

[12] M. S. Hill, P. B. Hitchcock, Chem. Commun. 2004, 1818.

[13] A. Kuczkowski, S. Heimann, A. Weber, S. Schulz, D. Bläser, C. Wölper, Organometallics 2011, 30, 4730.

[14] a) G. C. Welch, R. R. S. Juan, J. D. Masuda, D. W. Stephan, Science 2006, 314, 1124; b) M. Ullrich, A. J. Lough, D. W. Stephan, J. Am. Chem. Soc. 2009, 131, 52; c) C. M. Mömming, E. Otten, G. Kehr, R. Fröhlich, S. Grimme, D. W. Stephan, G. Erker, Angew. Chem. 2009, 121, 6770; Angew. Chem. Int. Ed. 2009, 48, 6643.

[15] T. Chu, I. Korobkov, G. I. Nikonov, J. Am. Chem. Soc. 2014, dx.doi.org/10.1021/ja5038337.

[16] L. R. Sita, R. D. Bickerstaff J. Am. Chem. Soc. 1988, 110, 5208.

[17] I. L. Fedushkin, A. S. Nikipelov, K. A. Lyssenko, J. Am. Chem. Soc. 2010, 132, 7874.

[18] Y. Peng, B. D. Ellis, X. Wang, J. C. Fettinger, P. P. Power, Science 2009, 325, 1668.

[19] a) R. Rodriguez, D. Gau, T. Kato, N. Saffon-Merceron, A. De Cózar, F. P. Cossío, A. Baceiredo, Angew. Chem. 2011, 123, 10598; Angew. Chem. Int. Ed. 2011, 50, 10414; b) R. Rodriguez, Y. Contie, D. Gau, N. Saffon-Merceron, K. Miqueu, J.-M. Sotiropoulos, A. Baceiredo, T. Kato, Angew. Chem. 2013, 125, 8595; Angew. Chem. Int. Ed. 2013, 52, 8437; c) F. Lips, J. C. Fettinger, A. Mansikkamäki, H. M. Tuononen, P. P. Power J. Am. Chem. Soc. 2014, 136, 634.

[20] J. W. Dube, C. M. E. Graham, C. L. B. Macdonald, Z. D. Brown, P. P. Power, P. J. Ragogna, Chem. Eur. J. 2014, 20, 6739.

[21] Bruker AXS D8 Kappa diffractometer with APEX2 detector (MoKa radiation, $\lambda=0.71073 \AA$ ). The structures were solved by Direct Methods (SHELXS-97, G. M. Sheldrick, Acta Crystallogr. Sect. A 1990, 46, 467) and refined by full-matrix least-squares on $\mathrm{F}^{2}$. Absorption corrections were performed semi-empirically from equivalent reflections on basis of multi-scans (Bruker AXS APEX2). All atoms were refined anisotropically. In the refinement of $\mathbf{2}$ and $\mathbf{4}$ distance and angle restraints for the disordered part were required. Only in $\mathbf{4}$ an anisotropic refinement of the disordered part was possible. For full crystallographic data including bond lengths and angles see SI.

[22] S. Schulz, A. Kuczkowski, M. Nieger, J. Organomet. Chem. 2000, 604, 202.

[23] S. Schulz, M. Nieger, Organometallics 1999, 18, 315 .

[24] S. Schulz, M. Nieger, J. Chem. Soc. Dalton Trans. 2000, 639.

[25] A. Kuczkowski, S. Schulz, M. Nieger, Eur. J. Inorg. Chem. 2001, 2605.

[26] P. Pyykkö, M. Atsumi, Chem. Eur. J. 2009, 15, 186. $\mathrm{r}_{\mathrm{cov}}(\mathrm{Al})=1.26 \AA$; $\mathrm{r}_{\mathrm{cov}}(\mathrm{Ga})=1.24 \AA ; \mathrm{r}_{\mathrm{cov}}(\mathrm{Sb})=1.40 \AA ; \mathrm{r}_{\mathrm{cov}}(\mathrm{Bi})=1.51 \AA$.

[27] For a review article see: S. Schulz, Adv. Organomet. Chem. 2003, 49, 225.

[28] Aside from these, Zintl-ions were structurally characterized: a) B. Weinert, F. Weigend, S. Dehnen, Chem.-Eur. J. 2012, 18, 13589; b) M. G. Morgan, M. Wang, W. Y. Chan, A. Mar, Inorg. Chem. 2003, 42, 1549; c) L. Xu, S. C. Sevov, Inorg. Chem. 2000, 39, 5383.

[29] $\left[\left(t-\mathrm{Bu}_{2} \mathrm{Sb}\right)(\mathrm{Cl}) \operatorname{In}\left(\mu-\mathrm{Sb} t-\mathrm{Bu}_{2}\right)\right]_{2}$ is the only structurally characterized compound containing a 1:2 stoichiometry. A. R. Barron, A. H. Cowley, R. A. Jones, C. M. Nunn, D. L. Westmoreland, Polyhedron 1988, 7,77 .

[30] a) H. A. Meinema, H. F. Martens, J. G. Noltes, J. Organomet. Chem. 1973, 51, 223; b) H. J. Breunig, D. Müller, Angew. Chem. 1982, 94 , 448-449; Angew. Chem., Int. Ed. Engl. 1982, 21, 439; c) H. J. Breunig, D. Müller, Z. Naturforsch. 1983, 38b, 125.

[31] G. R. Fulmer, A. J. M. Miller, N. H. Sherden, H. E. Gottlieb, A. Nudelman, Brian M. Stoltz, J. E. Bercaw, K. I. Goldberg, Organometallics 2010, 29, 2176. 


\section{Angewandte}

Entry for the Table of Contents (Please choose one layout)

Layout 2:

\section{Electron shuffle}

Chelladurai Ganesamoorthy, Dieter Bläser, Christoph Wölper, Stephan Schulz ${ }^{*}$ Page - Page

Temperature-dependant Electron Shuffle in Molecular Group 13/15 Intermetallic Complexes

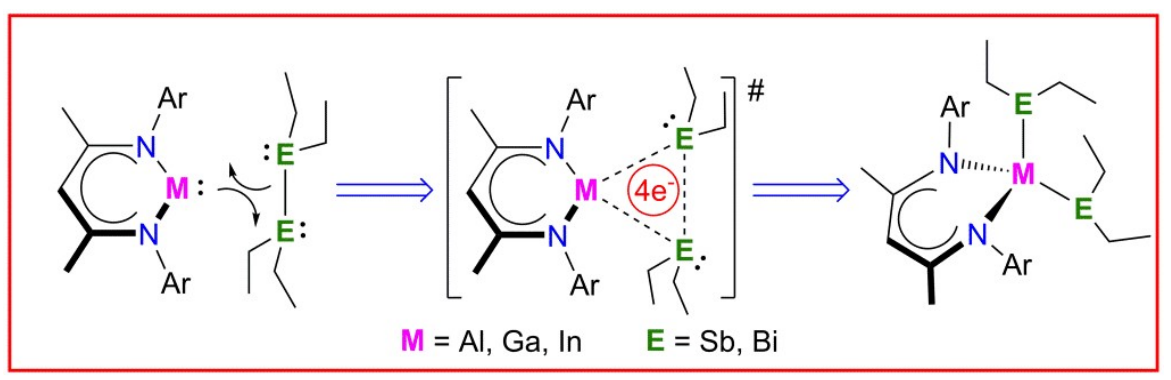

Reactions of monovalent $\mathrm{RAI}$ with $\mathrm{E}_{2} \mathrm{Et}_{4}(\mathrm{E}=\mathrm{Sb}, \mathrm{Bi})$ proceed with $\mathrm{E}-\mathrm{E}$ bond cleavage and formation of $\mathrm{RAl}\left(\mathrm{EEt}_{2}\right)_{2}$, whereas $\mathrm{RGa}$ forms a reversible chemical equilibrium with $\mathrm{E}_{2} \mathrm{Et}_{4}$ and $\mathrm{RGa}\left(\mathrm{EEt}_{2}\right)_{2}$. RIn does not react with $\mathrm{Sb}_{2} \mathrm{Et}_{4}$, but also forms a reversible equilibrium with $\mathrm{Bi}_{2} \mathrm{Et}_{4}$ at low temperatures. 
This text is made available via DuEPublico, the institutional repository of the University of Duisburg-Essen. This version may eventually differ from another version distributed by a commercial publisher.

DOI: $\quad 10.1002 /$ anie.201406304

URN: urn:nbn:de:hbz:464-20201119-180821-3

This is the peer reviewed version of the following article:

Angew. Chem. Int. Ed. 2014, 53, 11587-11591, which has been published in final form at: https://doi.org/10.1002/anie.201406304

All rights reserved. 